\title{
Comparative Evaluation of PI and Fuzzy Logic Controller for PV Grid-Tie Quasi Z-Source Multilevel Inverter
}

\author{
Devaraj Umarani $^{1 \mathrm{a}}$, Ramalingam Seyezhai ${ }^{\text {tb }}$, Sambasivan Dhivya ${ }^{1 \mathrm{c}}$
}

RECEIVED ON 11.04.2020, ACCEPTED ON 20.12.2020

\begin{abstract}
This paper portrays a comparative analysis report of Proportional-Integral (PI) and Fuzzy Logic Controller (FLC) for total Power control of Photovoltaic (PV) based grid-tie single-phase five- level Quasi Z-Source Inverter (qZSI). The adopted power control scheme allows for independent maximum power point tracking (MPPT) and independent control of DC link voltage in each $\mathrm{H}$-bridge of the proposed inverter. This analysis is carried out to depict the differences in the performance of both the controllers. It also demonstrates the suitability of the controllers for the proposed topology. The proposed inverter has the advantages of reduction in size of the impedance network, negligence of boost converter stage and boosting of voltage with the help of 9shoot through states. The power control scheme has been implemented with both PI controller and FLC. Simulation has been carried out using MATLAB software and the results are presented.
\end{abstract}

Keywords: Photovoltaic, Quasi Z-Source Inverter, PI-Controller, Fuzzy Logic Controller, MPPT, DC Link Voltage control.

\section{INTRODUCTION}

$\mathrm{G}$ rid-Connected PV systems turned out to be the promising renewable energy generation system in recent days due to their effective utilization of solar energy and clean power production. With the remarkable improvements in the solar PV technology, the cost has been declining year by year. A converter is needed to convert DC power fed from the $\mathrm{PV}$ into AC power to feed the grid. Among various topologies that are available for DC-AC power conversion, the candidate Quasi Z-Source Inverter stays aloof because of its various advantages. This voltage fed inverter does not require a DC-DC boost converter stage. Yet, it converts the DC-AC directly without any additional converter stages including boosting of voltage. Also, by cascading the H-bridges, the qZSI procures the advantages of cascaded Multilevel Inverter (MLI) such as modularity, suitability to PV/Fuel Cell and improved power quality [1-2]. This paper illustrates the controller design for PV based grid-tie qZSI. The control strategy involves separate MPPT for each solar array, DC link voltage control for each of the H-bridge and total grid power control.

PI controller is generally used to remove the Steady State Error (SSE). However, the stability and response of the system has a negative effect. Therefore, they are used in systems where the speed is not considered as a factor. Since PI controller cannot predict the future errors, the rise time and oscillations of the system cannot be decreased. So, an Artificial Intelligence (AI) controller can be implemented to control the proposed system to overcome the aforementioned disadvantages of PI controller. Fuzzy logic controller has been implemented for qZSI and compared with the results achieved by PI controller.

This paper is organized as follows. The overview of

${ }^{1}$ REC Laboratory, Department of Electrical and Electronic Engineering, Sri Sivasubramaniya Nadar College of Engineering, Chennai, India.

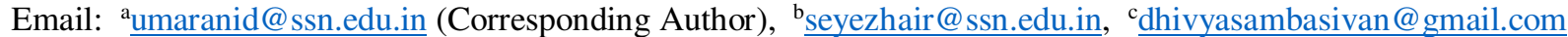
This is an open access article published by Mehran University of Engineering and Technology, Jamshoro under CC BY 4.0 International License. 
the single phase five-level qZSI is provided in Section 2. Design of LC network is presented in Section 3. The detailed control strategy of the qZSI is elaborated in Section 4. Section 5 and Section 6 focus on the grid side control of PI and FL controller. Comparison of both the controllers is explained in Section 7 followed by conclusion.

\section{SINGLE-PHASE FIVE-LEVEL QUASI Z-SOURCE INVERTER}

The Quasi Z-source inverter is one of the impedance inverters that can operate in buck and boost mode. In addition this it can provide AC output voltage for the applied DC input voltage in a single stage. This becomes possible because of the unique LC network that connects the PV source and the inverter's $\mathrm{H}$ bridge [3-4]. Fig.1 shows the PV based five-level qZSI. The voltage fed qZSI is different from the conventional voltage fed inverter as it operates in two states. The non-shoot through state consists of active and zero states. In this state, the qZSI acts like a current source when viewed from the PV side. In the shoot-through state, the switches pertaining to the same leg simultaneously conducts yet preventing the occurrence of short circuit of the PV source [5-6]. Fig.2 represents the non- shoot through state of qZSI and Fig.3 shows the shoot-through state of qZSI. Moreover, this type of inverter draws continuous current from the PV source making it well suited for PV applications. The single stages can be cascaded to get multilevel output with reduced Total Harmonic Distortion (THD). The modularity of this inverter is advantageous for renewable energy sources especially PV.

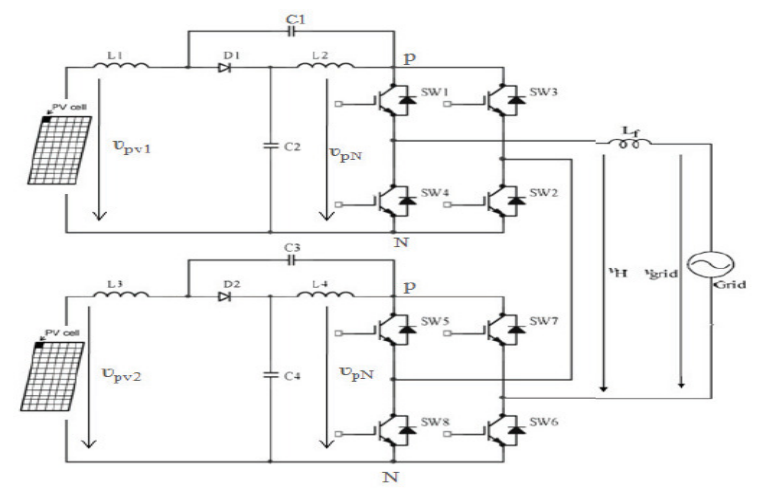

Fig. 1: PV based five-level qZSI

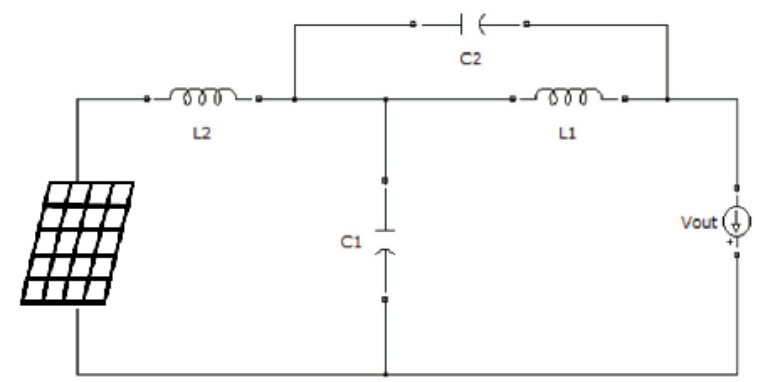

Fig.2: Non-Shoot-through state of qZSI

In non-shoot through state, the power is delivered from PV source to grid. During the shoot through state, the power delivered to the load will be zero. During this time period, the impedance network involves in boosting the input voltage [7].

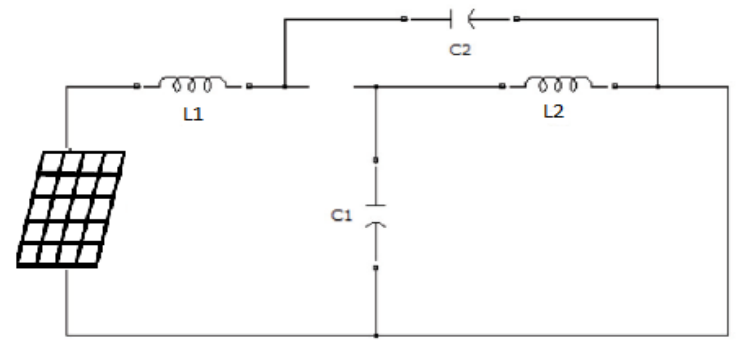

Fig.3: Shoot-through state of qZSI

The basic relationships based on the operating states are given below:

$$
\begin{aligned}
& \mathrm{V}_{\mathrm{C} 1}=\frac{1-\mathrm{D}}{1-2 \mathrm{D}} \mathrm{V}_{\mathrm{PV}} \\
& \mathrm{V}_{\mathrm{C} 2}=\frac{\mathrm{D}}{1-2 \mathrm{D}} \mathrm{V}_{\mathrm{PV}} \\
& \mathrm{V}_{\mathrm{PN}}=\frac{1}{1-2 \mathrm{D}} \mathrm{V}_{\mathrm{PV}}=\mathrm{B} \cdot \mathrm{V}_{\mathrm{PV}} \\
& \mathrm{V}_{\mathrm{ac}}=\frac{\mathrm{V}_{\mathrm{PV}}}{2} \cdot \mathrm{M} \cdot \mathrm{B}=\frac{\mathrm{M} \cdot \mathrm{V}_{\mathrm{PN}}}{2} \\
& \mathrm{~B}=\frac{1}{1-2 \mathrm{D}} \\
& \mathrm{D}=\frac{\mathrm{T}_{\mathrm{sh}}}{\mathrm{T}_{\mathrm{s}}}
\end{aligned}
$$

where, $\mathrm{D}$ is the shoot through duty ratio, $\mathrm{B}$ is the boost factor, $\mathrm{V}_{\mathrm{PV}}$ is the $\mathrm{PV}$ input voltage, $\mathrm{M}$ is the modulation index, $\mathrm{V}_{\mathrm{PN}}$ is the $\mathrm{DC}$ link voltage and $\mathrm{T}_{\mathrm{S}}$ 9is the switching time period. 


\section{DESIGN OF LC NETWORK FOR QZSI}

There is always an inherent second harmonic power flow associated with a single-phase system. So, second harmonic analysis called $2 \omega$ ripple analysis is carried out to design the impedance network of the qZSI. This design method results in reduced size of impedance network compared to the passive methods [8-9]. The design equations are given below.

qZS Capacitance is $\mathrm{C}=\frac{2 \mathrm{~V}_{\mathrm{o}} \mathrm{I}_{\mathrm{o}}}{\omega \varepsilon \mathrm{V}_{\mathrm{PN}}{ }^{2}}$

qZS Inductance is $\mathrm{L}=\frac{\mathrm{D}(1-\mathrm{D}) \mathrm{T}_{\mathrm{s}} \mathrm{V}_{\mathrm{DC}}}{(1-2 \mathrm{D}) \cdot 2 \cdot \Delta \mathrm{i}}$

From (7) and (8), the values of inductance $\mathrm{L}_{1}, \mathrm{~L}_{2}$ and capacitance $\mathrm{C}_{1}, \mathrm{C}_{2}$ are calculated as $3 \mathrm{mH}$ and $1100 \mu \mathrm{F}$ respectively.

\section{CONTROL STRATEGY FOR PV BASED GRID TIED SINGLE-PHASE FIVE-LEVEL QZSI}

To properly operate the PV based grid connected single-phase five-level qZSI, it is necessary to control the independent solar array voltages, the power injection on the grid side and the DC link voltages. The control objectives of the proposed system are: 1) Independent MPPT to each PV array for ensuring the extraction of maximum power; 2) the grid power injection at unity power factor with reduced THD; 3) Maintenance of equal DC link voltage in both the $\mathrm{H}$ Bridges [10].

The first control objective has been achieved by applying fuzzy logic MPPT. To each of the PV array, an independent fuzzy MPPT is implemented. The rule base is appropriately formed to ensure maximum PV power extraction. The second objective has been achieved by total power control on the grid side. Its function is to maintain the grid voltage and grid current in same phase. Thus unity power factor is maintained. The DC link voltages are maintained equal in all the H-bridges by using DC link voltage control which satisfies the third objective [11-12].

\subsection{Independent MPPT control using Fuzzy logic Control:}

Fuzzy Logic is a multi-rule-based algorithm. Compared to Neural Networks and Genetic
Algorithm, it provides quick and accurate results [1314]. Because of its faster convergence, the FL can be used for maximum power point tracking. From the measured voltage and current of the PV source at every instant, the power is estimated and stored as a vector. The FLC input variables are created based on (9) and (10).

$$
\begin{aligned}
& \mathrm{e}(\mathrm{t})=\frac{\Delta \mathrm{p}(\mathrm{t})}{\Delta \mathrm{v}(\mathrm{t})}=\frac{\mathrm{p}(\mathrm{t})-\mathrm{p}(\mathrm{t}-1)}{\mathrm{v}(\mathrm{t})-\mathrm{v}(\mathrm{t}-1)} \\
& \Delta \mathrm{e}(\mathrm{t})=\mathrm{e}(\mathrm{t})-\mathrm{e}(\mathrm{t}-1)
\end{aligned}
$$

To implement FL for MPPT, the following steps are to be followed. The error and change in error are the input variables that are fuzzified. For the applied input value, the corresponding membership function returns a value. From the triangle membership function, the Max-Min method is applied to extract the value. Fig. 4, Fig. 5 and Fig. 6 show the input membership functions $\mathrm{e}, \Delta \mathrm{e}$ and output reference respectively. According to Mamdani method, set of rule base must be applied to the resulting membership functions. The rules are framed and listed in Table 1. Centroid method is applied for the Defuzzification. The defuzzified output value is used as a reference signal for the generation of shoot through pulses.

The input and output surface waveform for fuzzy MPPT is shown in Fig.7.The separate MPPT control of the PV is shown in Fig. 8.

\begin{tabular}{|c|c|c|c|c|c|c|c|}
\hline \multicolumn{7}{|c|}{ Table 1: Rule base for Fuzzy MPPT } \\
\hline $\mathbf{A e}$ & NB & NM & NS & ZE & PS & PM & PB \\
\hline e & & & & & & & \\
\hline NB & M & M & M & VVS & VVS & VVS & VVS \\
\hline NM & M & M & M & VS & VS & VS & VS \\
\hline NS & S & M & M & S & S & S & S \\
\hline ZE & VS & S & M & VB & M & B & VB \\
\hline PS & VB & B & B & VB & M & M & B \\
\hline PM & VB & VB & VB & VB & M & M & M \\
\hline PB & VVB & VVB & VVB & VVB & M & M & M \\
\hline
\end{tabular}

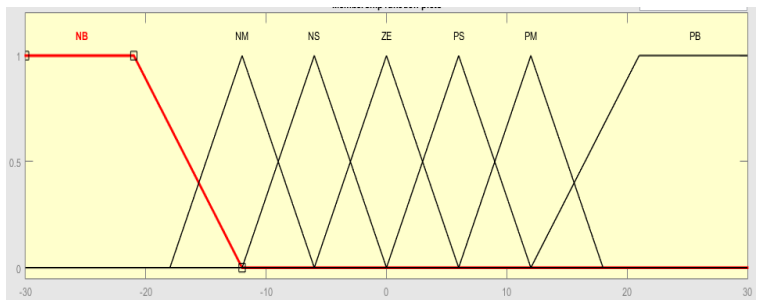

Fig.4: Input variable 1: Error (e) membership functions 


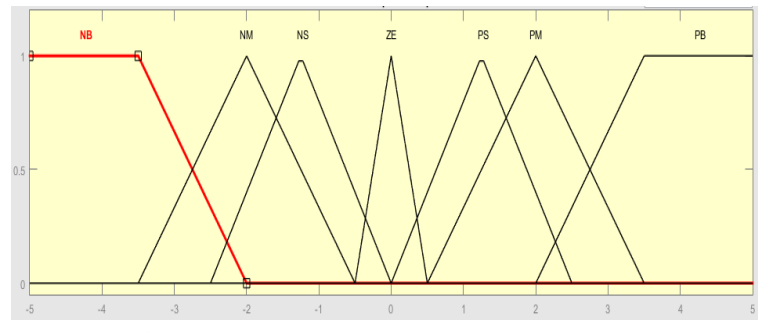

Fig.5: Input variable 2: Change in error $(\Delta \mathrm{e})$ membership functions

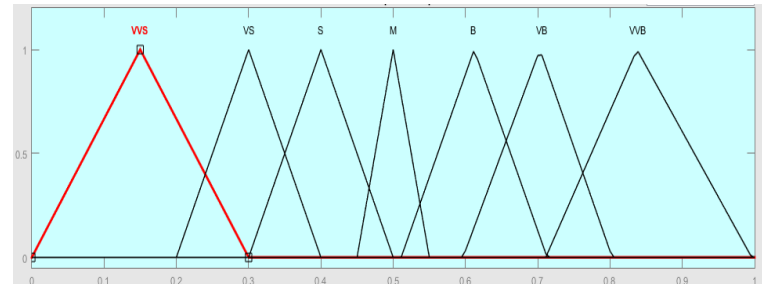

Fig.6: Membership functions of output variable

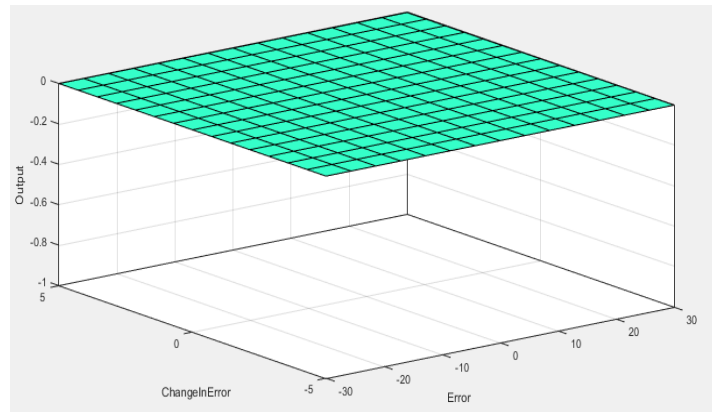

Fig.7: Input and output surface waveforms of fuzzy MPPT

The PV specifications are listed in Table 2. Fuzzy logic MPPT is implemented for each PV module and the output current, voltage and power waveforms are shown in Fig.10.

\begin{tabular}{|c|c|c|c|}
\hline \multicolumn{4}{|c|}{ Table 2: PV Specifications } \\
\hline \multicolumn{4}{|c|}{ Each PV module specification } \\
\hline \multicolumn{2}{|c|}{ Parameter } & Rating & Unit \\
\hline Open Circuit Voltage & Voc & 21.4 & $\mathrm{~V}$ \\
\hline Short Circuit Current & Isc & 7.1 & A \\
\hline Max. Power & $\mathrm{Pm}$ & 110.5 & $\mathrm{Wp}$ \\
\hline Max. Voltage & $\mathrm{Vm}$ & 17 & $\mathrm{~V}$ \\
\hline Max. Current & $\operatorname{Im}$ & 6.5 & $\mathrm{~A}$ \\
\hline \multicolumn{4}{|c|}{ No. of PV modules required per H-Bridge } \\
\hline $\mathrm{Np}$ & & & 1 \\
\hline Ns & & & 6 \\
\hline $\mathrm{Np} \times \mathrm{Ns}$ & & & 6 \\
\hline
\end{tabular}

The output reference from Fuzzy Logic MPPT is used to generate the shoot through duty ratio that exclusively controls the PV voltage to operate at maximum power point.

\subsection{Grid Side Control}

The grid side controller involves the control of DC link voltage and injected power from grid. The DC link voltage is maintained at an equal value in each of the qZSI H-Bridge. This can be implemented by adopting DC link voltage conrol which maintains the DC link voltage $\mathrm{V}_{\mathrm{PN}}$ as the sum of capacitor voltages $\mathrm{V}_{\mathrm{Cl}}$ and $\mathrm{V}_{\mathrm{C} 2}$ of the LC network. Two voltage sensors are required in each qZSI H-bridge to measure the capacitor voltages. The sum of these voltages are subtracted from the reference DC link voltage. A controller is now employed to adjust the output power reference $\mathrm{P}_{\mathrm{n}}^{*}$ based on the variations in the capacitor voltages. The reference value of $\mathrm{P}_{\mathrm{n}}^{*}$ varies with variation in PV output power. In this paper, DC link voltage controller is designed and implemented with both fuzzy logic and proportional-integral control.

The independent MPPT control and DC link voltage control schemes are represented by Fig. 8 and Fig. 9 respectively.

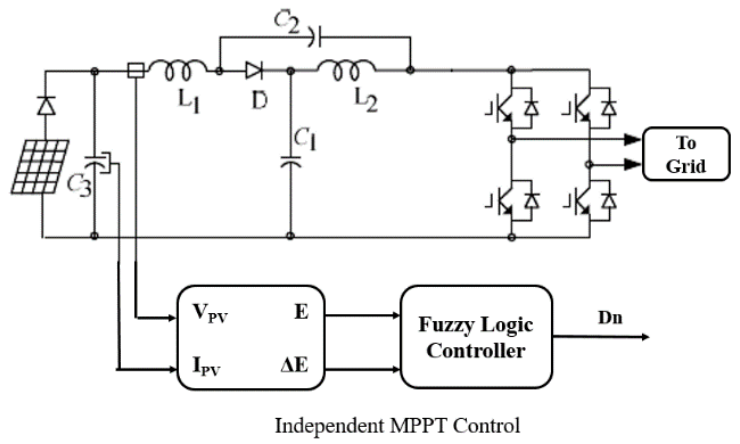

Fig.8: Independent MPPT control

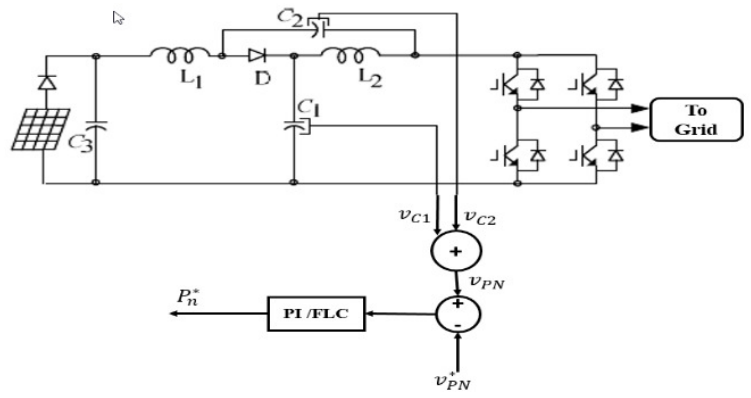

Fig 9: DC link voltage control 
The total power injected to the grid is the addition of each PV string output power, $\mathrm{P}_{\text {total }}^{*}$, The total grid power control is shown in Fig.10. This control is essential to ensure phase locking of sinusoidal grid voltage and grid current. The peak value of grid current is given by,

$\mathrm{i}_{\mathrm{g}}{ }^{*}=\frac{2 \mathrm{P}_{\mathrm{n}}^{*}}{\mathrm{v}_{\mathrm{g}, \text { peak }}}$

The phase of the grid voltage is measured using Phase Locked Loop (PLL) and hence unity power factor operation is ensured. The power reference $\mathrm{P}_{\mathrm{n}}^{*}$ generated by the DC link voltage control is used to create reference grid current $\mathrm{i}_{\mathrm{g}}^{*}$. The measured grid current is applied to the current control loop. A current controller is implemented to generate reference signal for the pulse width amplitude modulation strategy. The PWAM pulses along with shoot through from fuzzy MPPT, gating pulses are generated for the qZSI.

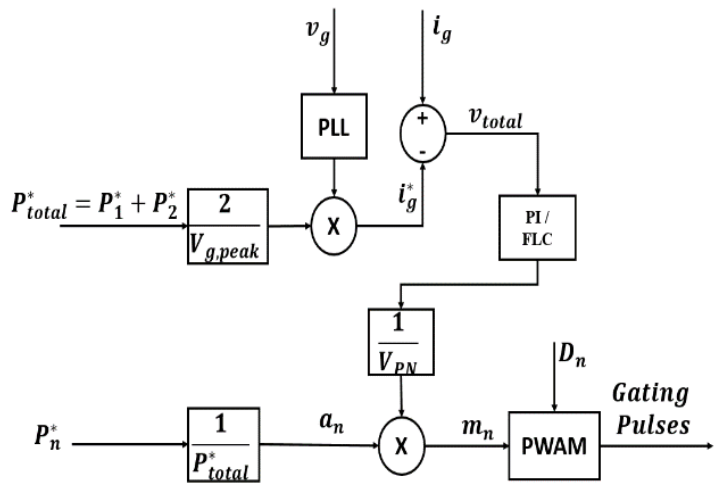

Fig.10 Total grid power control

This paper illustrates the design of FLC and PI controller for grid side control. The parameters of both the controllers are presented in the next section.

\section{Grid Side Control USING PI Controller}

To maintain the DC link voltage at the required value, the capacitor voltages $\mathrm{V}_{\mathrm{C} 1}$ and $\mathrm{V}_{\mathrm{C} 2}$ are measured, summed up and compared with reference $\mathrm{V}_{\mathrm{PN}}$. The error is fed to a PI controller and $K_{P}$ and $K_{I}$ values are tuned to generate the output power reference $P_{n}^{*}$. These values are selected by using trial and error method [15]. To control the grid power, the grid current is measured and compared with current reference and the error is given to another PI controller for generating a reference signal to control the modulation signal of the PWAM. Fig. 11 shows the Simulink model of grid side controller with PI control.
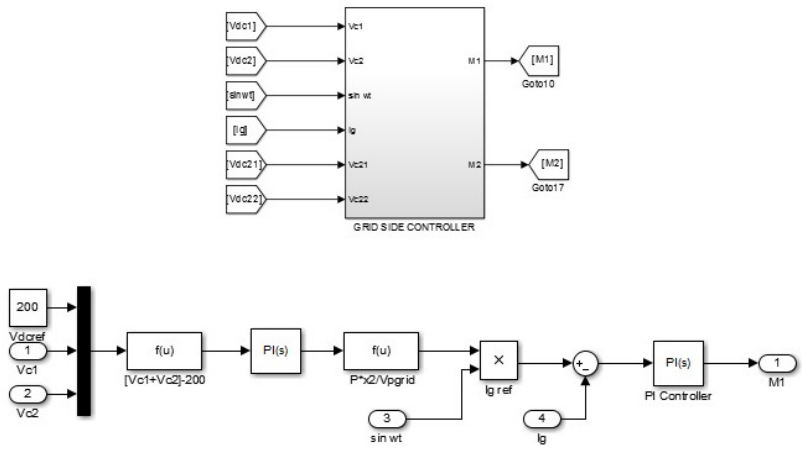

Fig.11: Simulink model of grid side controller

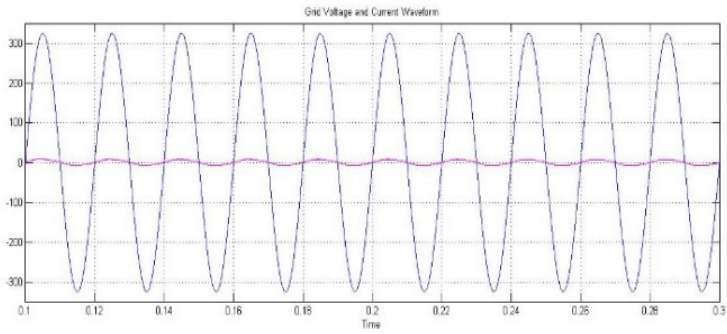

Fig.12: Grid voltage and grid current with PI controller

The grid injected current with peak value of $7.7 \mathrm{~A}$ is obtained. Grid current is in phase with the grid voltage, thus ensuring unity power factor operation. The grid voltage, current and multilevel inverter output are shown in Fig.13.
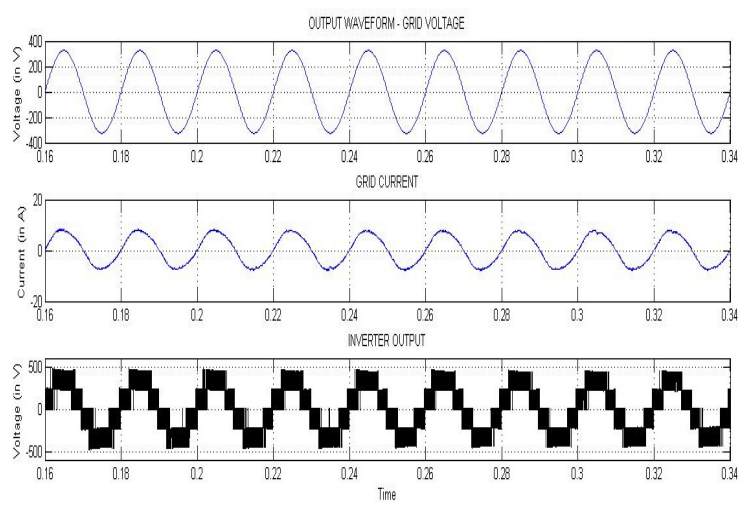

Fig. 13: Peak values of Grid Voltage, Grid Current and Five-Level Voltage 
The grid peak voltage is maintained at $325 \mathrm{~V}$, peak grid current at 7.7A and they are locked in phase with each other.

\section{Grid Side CONTROL USING FUZZY LOGIC CONTROLLER}

FL controller for peak DC-link voltage control has inputs such as error and change in error. The difference between DC link voltage reference and sum of two capacitor voltages $\mathrm{V}_{\mathrm{C} 1}$ and $\mathrm{V}_{\mathrm{C} 2}$ with respect to reference DC-link voltage is taken as Error input. Fig.14a and 14b shows the input membership functions such as error and change in error respectively for DC link voltage control.

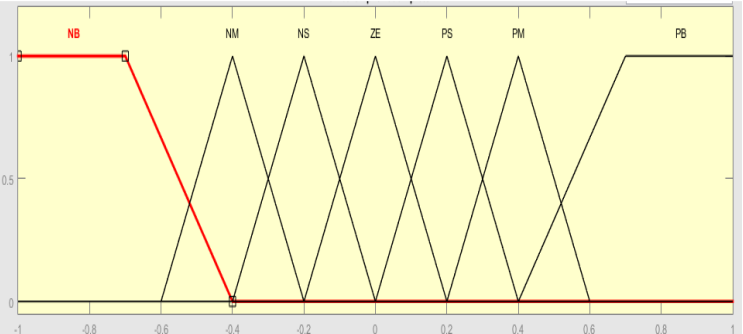

Fig 14a: Error (e) for DC link voltage control

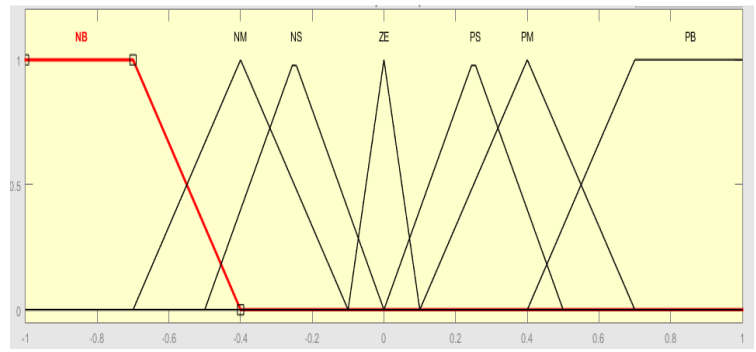

Fig 14b: Change in Error $(\Delta \mathrm{e})$ for DC link voltage control

Fig. 15 shows the membership functions of the output variable of DC link voltage controller.

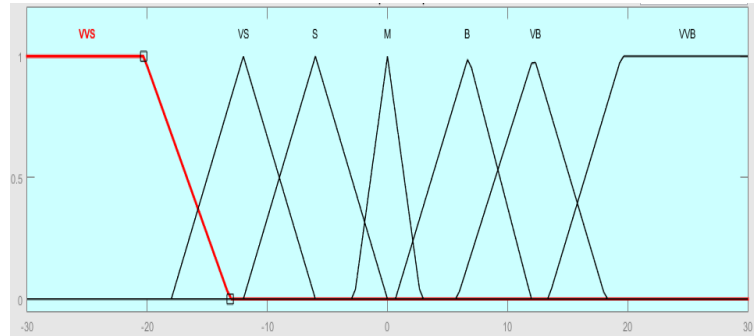

Fig.15: Output variable: Power reference
The fuzzy rule base for DC link voltage control are listed in Table 3. Mamdani fuzzy inference system (FIS) uses fuzzy variables and fuzzy rules to achieve rule strength. Largest of Maximum (LOM) method is used to get defuzzified output power reference. The peak value of grid current reference is obtained from this controller output. Fig. 16 and Fig. 17 shows the input and output membership functions of the grid current control.

\begin{tabular}{|c|c|c|c|c|c|c|}
\hline \multicolumn{7}{|c|}{$\begin{array}{l}\text { Table 3: Fuzzy Rule Base for DC-link Voltage } \\
\text { Control }\end{array}$} \\
\hline $\begin{array}{l}\text { Change } \\
\text { in } \\
\text { error }\end{array}$ & NB & $\mathbf{N M}$ & $\mathbf{N S}$ & $\mathbf{P S}$ & $\mathbf{P M}$ & PB \\
\hline \multicolumn{7}{|l|}{ Error } \\
\hline NB & NB & ZE & NB & NB & NB & NB \\
\hline NM & ZE & $\mathrm{ZE}$ & NM & $\mathrm{NM}$ & $\mathrm{NM}$ & $\mathrm{NM}$ \\
\hline NS & NS & $\overline{\mathrm{ZE}}$ & NS & NS & NS & NS \\
\hline $\mathbf{Z E}$ & NM & NS & $\mathrm{ZE}$ & $\mathrm{ZE}$ & PS & PM \\
\hline PS & PM & PS & $\mathrm{PM}$ & $\mathrm{ZE}$ & ZE & PS \\
\hline $\mathbf{P M}$ & PM & PM & PM & $\overline{\mathrm{ZE}}$ & ZE & $\overline{Z E}$ \\
\hline PB & PB & PB & $\overline{\mathrm{PB}}$ & $\mathrm{ZE}$ & ZE & ZE \\
\hline
\end{tabular}

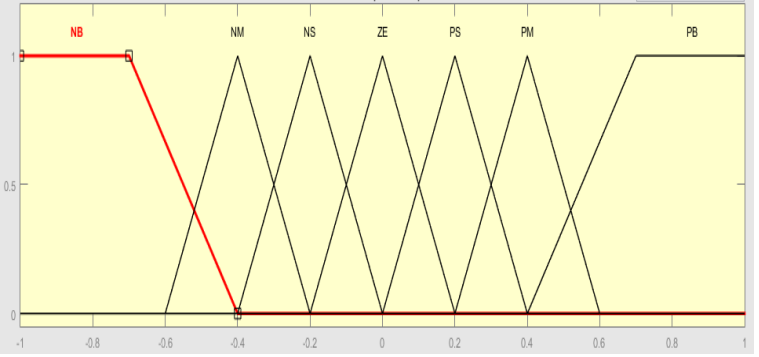

Fig 16(a): Error (e) for grid current control

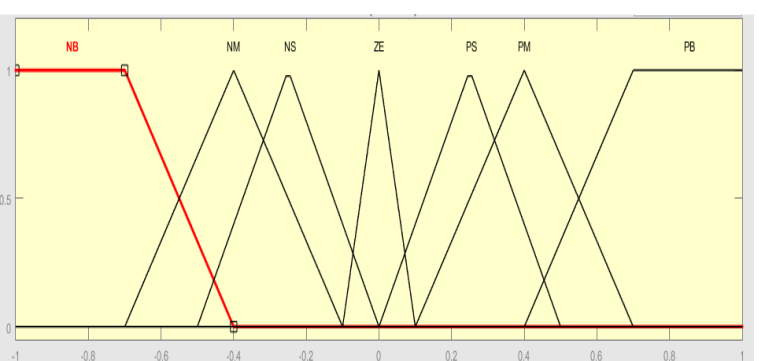

Fig 16(b): Change in Error $(\Delta \mathrm{e})$ for grid current control

Fig. 17 shows the membership functions of the output variable of DC link voltage controller. 
The surface view of the fuzzy rule base for grid current control is shown in Fig. 18.

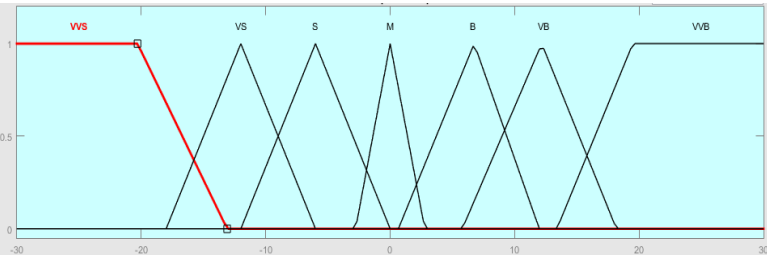

Fig.17: Output variable: Modulation index

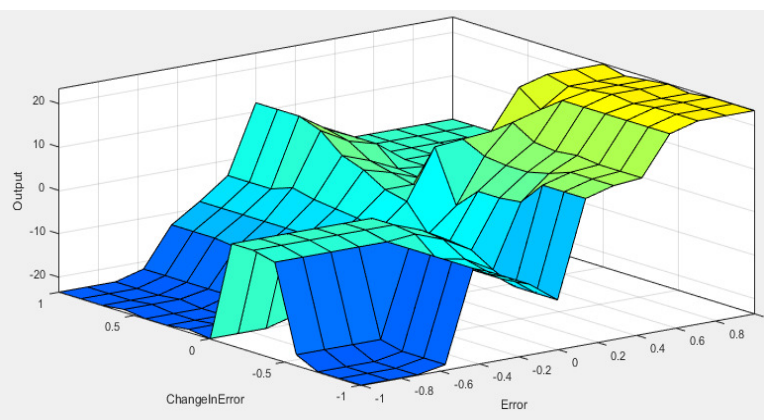

Fig 18. Fuzzy rule base for grid current control

Fig. 19 shows the Simulink diagram of grid side fuzzy logic controller.
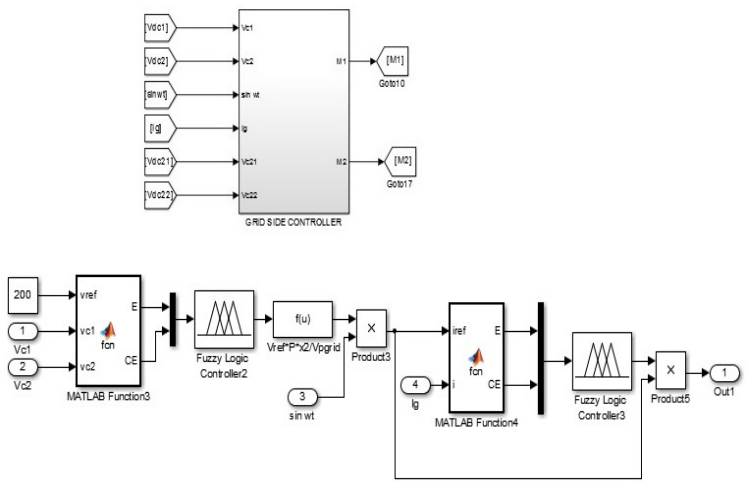

Fig 19: Simulink diagram of grid side fuzzy logic controller

The grid injected current of 7.528 A peak is obtained. Grid current is in phase with the grid voltage, thus ensuring unity power factor operation. Fig. 20 shows the grid voltage and current waveform.

The peak value of grid voltage is obtained as $325 \mathrm{~V}$ and peak grid current is obtained as 7.53A. The grid voltage and current are locked and in-phase with each other. other. Fig.21 shows the peak values of grid voltage, grid current and five-level output waveform.

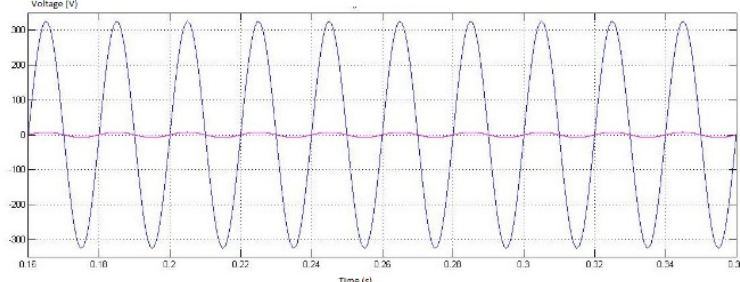

Fig 20: Grid voltage and grid current with FLC
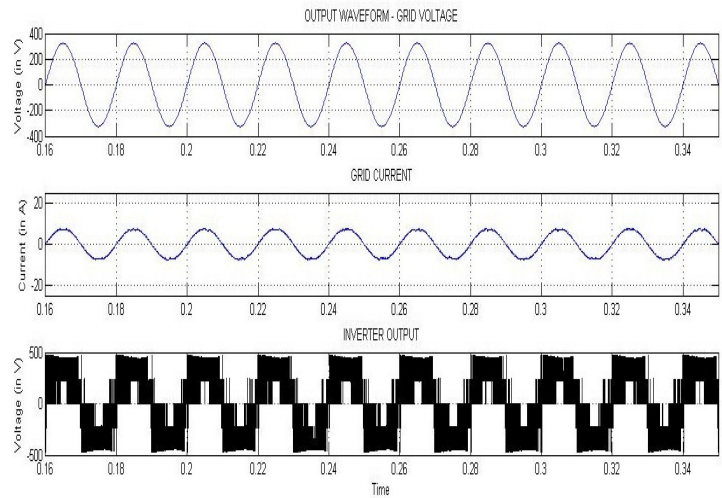

Fig 21: Peakvalues of Grid voltage, Grid current and five-level voltage

\section{COMPSRISON OF CONTROLLER PARAMERTS}

The parameters of PI controller and FLC implemented for PV based grid tied five-level qZSI are compared and results are presented below. Fig. 22 and Fig. 23 represents the THD of grid current obtained using PI and FLC respectively.

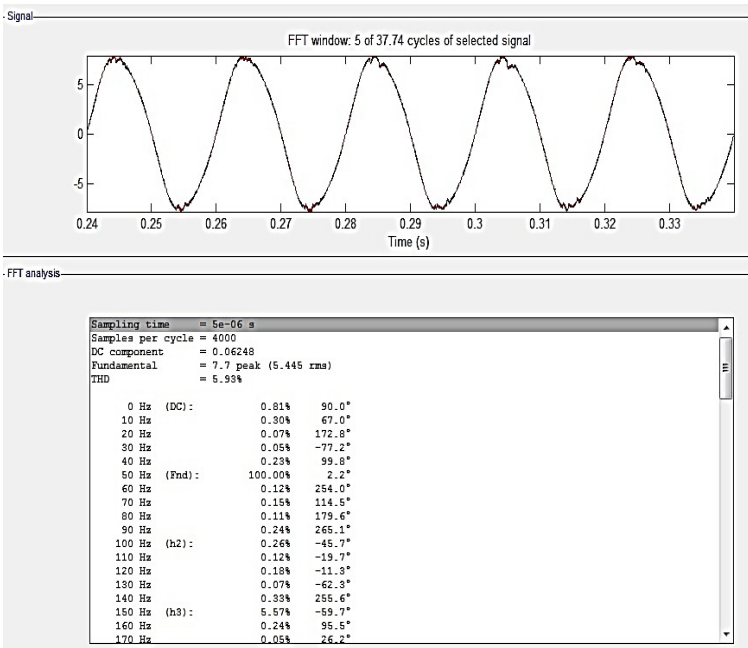

Fig 22: Current THD with PI controller 


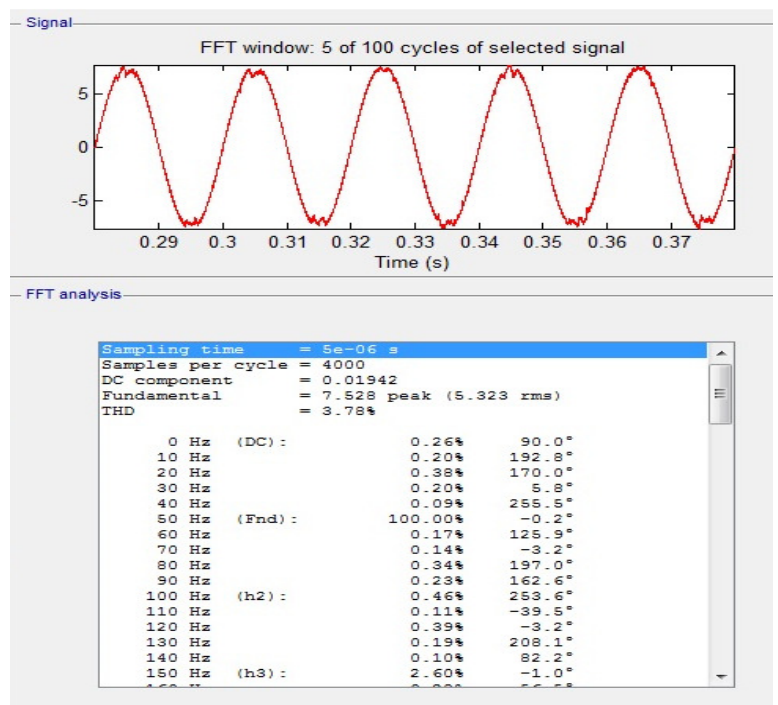

Fig 23: Current THD with FLC

The comparison of controller parameters are given in Table 4. The grid current THD is obtained as 5.93\% with PI controller and $3.78 \%$ with FLC. The rise time and settling time of the PI controller are $0.02 \mathrm{~s}$ and 0.08 s respectively. Using FL controller, the rise time and settling time are found to be $0.016 \mathrm{~s}$ and $0.05 \mathrm{~s}$. The steady state error is found to be 0.13 for FLC and 0.2 for PI controller. Thus from table 4, it can be inferred that FLC serves to be the better controller for the proposed topology.

\begin{tabular}{|c|c|c|}
\hline \multicolumn{3}{|c|}{ Table 4: Comparison of Controller Parameters } \\
\hline Parameters & Pi Controller & Fl Controller \\
\hline Rise time, $\mathrm{t}_{\mathrm{r}}$ & $0.02 \mathrm{~s}$ & $0.016 \mathrm{~s}$ \\
\hline $\begin{array}{c}\text { Settling } \\
\text { time, } \mathrm{t}_{\mathrm{s}}\end{array}$ & $0.08 \mathrm{~s}$ & $0.05 \mathrm{~s}$ \\
\hline $\begin{array}{c}\text { Steady state } \\
\text { error, } \mathrm{e}_{\mathrm{ss}}\end{array}$ & 0.2 & 0.13 \\
\hline $\begin{array}{c}\text { Current } \\
\text { THD }\end{array}$ & $5.93 \%$ & $3.78 \%$ \\
\hline
\end{tabular}

\section{Conclusion}

The total power control technique of PV connected grid-tie qZS multilevel inverter was proposed. The controllers such as PI and fuzzy logic control were implemented to compare their performance parameters.For independent MPPT to each PV array, fuzzy MPPT was implemented. For grid side power control, inner current control and DC link voltage control was implemented using both PI and FLC.The rise time and settling time of FL Controller is $0.016 \mathrm{~s}$ and $0.05 \mathrm{~s}$ respectively which is lesser than PI controller. The steady state error of 0.13 obtained by FLC is lesser compared to 0.2 of PI controller. The current THD of $3.78 \%$ is obtained while using FL controller whereas the current THD obtained using PI controller exceeds $5 \%$. Therefore, while the controller parameters are compared, in all the aspects, the FLC is found to be the best suitable controller for PV based grid-tie five-level qZSI. The results are validated and discussed.

\section{ACKNOWLEDGEMENT}

The authors would like to sincerely thank the SSN management and SSN trust for funding the research work.

\section{REFERENCES}

1. Rodriguez J., Lai J.-S., Peng F. Z., "Multilevel inverters: A survey of topologies, controls, applications", IEEE Transactions on Industrial Electronics, Vol. 49, No. 4, pp. 724-738, August 2002.

2. Alonso O., Sanchis P., Gubia E., Marroyo L., "Cascaded H-bridge multilevel converter for grid connected photovoltaic generators with independent maximum power point tracking of each solar array", Proceedings of the IEEE 34th Annual Power Electronics Specialist Conference, Acapulco, Mexico, Vol. 2, pp. 731-735, 15-19 June, 2003.

3. Sun D., Ge B., Fang, Peng F.Z., Haitham A.R., Bi B., Liu Y., "A new grid-connected PV system based on cascaded $\mathrm{H}$ bridge quasi- $\mathrm{Z}$ source inverter", Proceedings of the IEEE International Symposium on Industrial Electronics, Hangzhou, China, pp. 951-956, May 28-31, 2012.

4. Anderson J., Peng F.Z., "Four Quasi-Z-Source Inverters", Proceedings of the IEEE Power Electronics Specialists Conference, Rhodes, Greece, pp. 2743-2749, June 2008.

5. Huang Y., Shen M.S., Peng F.Z., Wang J., "ZSource inverter for residential photovoltaic systems," IEEE Transactions on Power 
Electronics, Vol. 21, no. 6, pp. 1776-1782, November 2006.

6. Li Y., Anderson J., Fang Z.P., Liu D., "Quasi-Z Source Inverter for Photovoltaic Power Generation Systems", Proceedings of the IEEE Applied Power Electronics Conference, pp. 918924, 2009.

7. Li Y., Anderson J., Peng F.Z., Liu D.C., "QuasiZ-source inverter for photovoltaic power generation systems," Proceedings of the TwentyFourth IEEE Annual Applied Power Electronics Conference and Exposition, Washington DC, USA, pp. 918-924, 15-19 February 2009.

8. Seyezhai R., Umarani D., "Study of Z-Source Inverter Impedance Networks using $2 \omega$ Analysis for Photovoltaic Applications", Applied Mechanics and Materials, Vol. 852, pp 867-874, September 2016.

9. Ge B., Haitham A-R, Liu Y., Robert S.B. "Minimized Quasi-Z source network for singlephase inverter", Proceedings of the Applied Power Electronics Conference and Exposition (APEC), IEEE, pp. 806-811, 2015.

10. Li Y. F.Z., Peng J.G., Cintron-Rivera, Jang S. J., "Controller design for Quasi-Z-Source inverter in photovoltaic systems," Proceedings of the IEEE Energy Conversion Congress and Exposition, Atlanta, USA, pp. 3187-3194, 12-16 Sep. 2010.

11. Ding X., Qian Z, Yang S., Cui B., Peng F., "A Direct Peak DC-link Boost Voltage Control Strategy in Z-Source Inverter", Proceedings of the 22 $2^{\text {nd }}$ IEEE Applied Power Electronics Conference and Exposition, Anaheim, USA, pp. 648-653, 25 February - 1 March 2007.

12. Park J. H., Kim H. G., Nho E. C., Chun T.W., Choi J., "Grid connected PV System Using a Quasi-Z-source Inverter," Proceedings of the 24tth IEEE Applied Power Electronics Conference and Exposition, Washington, DC, USA, pp. 925-929, 15-19 February 2009.
13. Kwan T.H., Wu X., "Maximum power point tracking using a variable antecedent fuzzy logic controller", Solar Energy, Vol. 137, pp.189-200, 2016.

14. Dabbaghjamanesh M., Moeini A., Ashkaboosi M., Khazaei P., Mirzapalangi K., "High performance control of grid connected cascaded $\mathrm{H}$-Bridge active rectifier based on type II-fuzzy logic controller with low frequency modulation technique", International Journal of Electrical and Computer Engineering, Vol. 6, No.2, pp. 484-494, 2016.

15. Tomer A. S., Satyprakash D., "Response Based Comparative Analysis of Two Inverter Fed Six Phase PMSM Drive by Using PI and Fuzzy Logic controller", International Journal of Electrical and Computer Engineering, Vol. 6, No. 6, pp. 2643-2657, 2016.

16. Husev O., Roncero-Clemente C., RomeroCadaval E., Vinnikov D. Jalakas T., Three-level three-phase quasi-Z-source neutral-pointclamped inverter with novel modulation technique for photovoltaic application, Electric Power Systems Research, Vol. 130, pp.10-21, 2016.

17. Liu Y., Haitham A-R, Baoming Ge., "Front-End Isolated Quasi-Z-Source DC-DC Converter Modules in Series for High-Power Photovoltaic Systems-Part II: Control, Dynamic Model, and Downscaled Verification", IEEE Transactions on Industrial Electronics, Vol. 64, No. 1, pp. 359368, 2017. 